\title{
Fine-Tuning of ENA ${ }^{\circledR}$ Gapmers as Antisense Oligonucleotides for Sequence-Specific Inhibition
}

\author{
MIHO TAKAGI-SATO,${ }^{1}$ SHINYA TOKUHIRO, ${ }^{2}$ REIMI KAWAIDA, ${ }^{2}$ and MAKOTO KOIZUMI ${ }^{2}$
}

\begin{abstract}
For gene validation and the development of oligonucleotide agents, $2^{\prime}$ - $O, 4^{\prime}$ - $C$-ethylene-bridged nucleic acid (ENA) antisense gapmers are widely available. An in vitro Escherichia coli $\mathrm{RNase} H$ reaction analysis using ENA gapmers and an RNA oligonucleotide with mouse peptidylarginine deiminase 4 (PADI4) gene sequences revealed that the RNA oligonucleotide was specifically cleaved in the only reported case of the use of an ENA gapmer with an antisense sequence. On the other hand, duplexes of the full-length transcripts of PADI4 mRNA and ENA gapmers with a wide DNA window were cleaved not only at the target site, but also at nontarget sites by RNase $H$ derived from partial base-pairing between the transcript and the ENA gapmer. When the DNA window region of the ENA gapmer was shortened to 5 or 6 nucleotides, the nontarget cleavage was effectively diminished. Moreover, the specific inhibition of PADI4 mRNA expression was observed in the cotransfection of PADI4 cDNA and ENA gapmers containing a short DNA region into NIH3T3 cells. These results demonstrated that ENA gapmers with a short DNA region improved the sequence-specificity of mRNA downregulation These optimized ENA gapmers could reduce the "off-target" effect and be applicable to gene validation and oligonucleotide therapeutics.
\end{abstract}

\section{INTRODUCTION}

$\mathbf{M}$ ANY MODIFIED OLIGONUCLEOTIDES are currently being designed as antisense oligonucleotides for gene validation and therapeutic agents (Zhang et al., 2000; Butler et al., 2002; Kurreck, 2003; Yu et al., 2005). Some of these modified oligonucleotides have been successfully used in clinical studies (Zinker et al., 2002; Crooke et al., 2005; Orum 2005). Most of them were modified with ribonucleotide analogues and form stable duplexes with complementary RNA (Kurreck, 2003). Fully modified oligonucleotides (FMOs) with ribonucleotide-type modifications are applied as translational arrest inhibitors and pre-mRNA splicing modulators (Baker et al., 1997; Sazani et al., 2002). However, the inhibitory activity of FMOs was relatively low because a duplex of mRNA with an FMO is not a substrate for RNase $\mathrm{H}$, which degrades the RNA strand in a
DNA/RNA heteroduplex (Monia et al., 1993; Braasch et al., 2002; Jepsen et al., 2004). To activate RNase H, chimeric oligonucleotides with a DNA region in the window and modified ribonucleotide regions in the wings are generally utilized as antisense strands named "gapmers" (Fig. 1A; Inoue et al., 1987; Monia et al., 1993). At least five DNA residues in the window are essential for a human RNase $\mathrm{H} 1$ reaction and at least four are necessary for an Escherichia coli RNase H1 reaction (Monia et al., 1993; Crooke et al., 1995). Longer DNA regions in the window are effective for RNase $\mathrm{H}$ reactions, and longer wing regions show higher affinity to target mRNA. Indeed, the initial cleavage rates increased according to the increase of the DNA gap size (Monia et al., 1993; Crooke et al., 1995; Wu et al., 1999; Lima et al., 2007a). The balance between the size of the window and the wings is essential for the design of efficient gapmers (Kurreck, 2003).

\footnotetext{
${ }^{1}$ Medicinal Chemistry Research Laboratories I, ${ }^{2}$ Advanced Technology Research Laboratories, Daiichi Sankyo Co., Ltd., 1-258, Hiromachi, Shinagawa-ku, Tokyo 140-8710, Japan

ENA is a registered trademark of Mitsubishi-Kagaku Foods Corporation.
} 
A

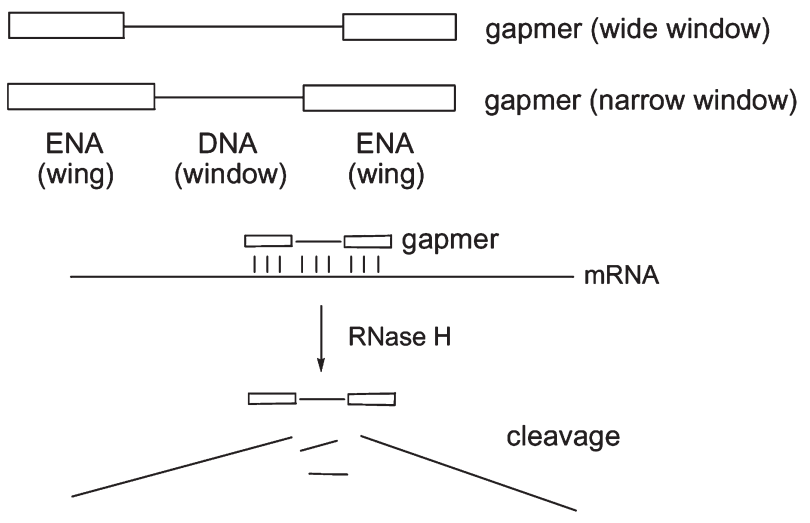

B
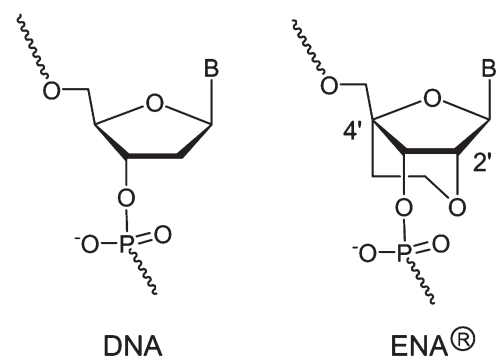

FIG. 1. A: Design of gapmers with a wide or narrow window and scheme of RNase $\mathrm{H}$ reaction using the gapmer. B: Structures of DNA and $2^{\prime}-O, 4^{\prime}-C$-ethylene-bridged nucleic acid (ENA).

One of the problems of an antisense strategy is that antisense oligonucleotides do not only bind to the target region but also partially hybridize to nontarget regions (Woolf et al., 1992). The resulting hydrids are substrates for RNase $\mathrm{H}$, causing cleavage of RNA at nontarget sites. To resolve this problem, the use of chimeric DNA methylphosphonate/phosphodiester as an antisense strand has been reported (Giles and Tidd, 1992; Larrouy et al., 1992). Only a few research studies on the specific cleavage of RNase $\mathrm{H}$ by gapmer antisense oligonucleotides modified with $2^{\prime}$-O-alkyl ribonucleotides have been reported (Larrouy et al., 1995; Lima and Crooke 1997; Shen et al., 1998; Lima et al., 2007b).

Recently, we reported the synthesis and properties of $2^{\prime}-O, 4^{\prime}$ - $C$-ethylene nucleic acids (ENA; Fig. 1B), that have a less-strained six-membered ring than the fivemembered ring of 2'-O,4'-C-methylene nucleosides, known as 2',4'-BNA or LNA (Obika et al., 1997, 2001; Koshkin et al., 1998; Morita et al., 2002, 2003). ENA oligonucleotides showed a binding affinity to RNA as high as that of $2^{\prime}, 4^{\prime}$-BNA/LNA $\left(\Delta T_{\mathrm{m}}=+3\right.$ to $\left.5^{\circ} \mathrm{C}\right)$ (Morita et al., 2002, 2003). Their ENA oligonucleotides also exhibited much higher nuclease resistance than $2^{\prime}, 4^{\prime}$-BNA/LNA oligonucleotides in a nuclease assay and a rat plasma stability assay (Morita et al., 2002, 2003,
2006). We showed the intracellular antisense activity or exon skipping activity of ENA oligonucleotides targeted to the organic anion transporting polypeptide (Takagi et al., 2004), vascular endothelial growth factor (Morita et al., 2006) or dystrophin (Surono et al., 2004). Moreover, the in vivo activity of an ENA oligonucleotide was compared with that of a $2^{\prime}$-O-(2-methoxy)ethyl oligonucleotide ISIS113715, each with a PTP1B antisense sequence (Koizumi et al., 2006). ENA oligonucleotides are considered to be candidates for the next-generation antisense molecules (Koizumi, 2006).

In the present report, in order to evaluate the function of the mouse peptidylarginine deiminase 4 (PADI4) gene, ENA gapmers with various length DNA regions as antisense oligonucleotides were designed (Takagi-Sato et al., 2006). Among them, ENA gapmers with a short DNA region improved the sequence-specificity of PADI4 mRNA downregulation.

\section{MATERIALS AND METHODS}

\section{Synthesis of oligonucleotides}

$2^{\prime}$ - $O, 4^{\prime}$ - $C$-Ethylene nucleoside- $3^{\prime}-O$-phosphoramidite units were prepared according to reported methods (Morita et al., 2002, 2003). Oligonucleotides with ENA residues were synthesized according to reported methods ((Morita et al., 2003; Horie et al., 2006).

The structures of the modified oligonucleotides were determined by negative-ion ESI mass spectroscopy. AS-1 calcd: 6754.57, found: 6755.9; AS-1-1 calcd: 6768.60, found: 6768.20; AS-1-2 calcd: 6754.57, found: 6754.21; AS-1-3 calcd: 6726.51, found: 6726.27; AS-1-4 calcd: 6740.54, found: 6740.39; AS-1 8MM calcd: 6848.6, found: 6848.65; S-1 calcd: 6811.40, found: 6811.9; S-1-1 calcd: 6825.60, found: 6825.23; S-1-2 calcd: 6825.60 , found: 6825.20; S-1-3 calcd: 6825.60, found: 6825.49; S-1-4 calcd: 6797.55, found: 6797.46. AS-2 calcd: 5860.88, found: 5860.3; AS-2-1 calcd: 5860.96, found: 5861.01; AS-2-2 calcd: 5860.96, found: 5861.01; AS-2-3 calcd: 5846.94, found: 5846.97; S-2 calcd: 5851.90, found: 5852.9; S-2-1 calcd: 5880.03, found: 5880.04; S-2-2 calcd: 5866.00, found: 5866.06; S-2-3 calcd: 5866.00, found: 5866.04. A 5'-FAM-labeled RNA oligonucleotide was synthesized with 6-FAM amidite (Applied Biosystems, Foster City, CA) using standard RNA phosphoramidite chemistry on an ABI 394 DNA/RNA synthesizer.

\section{Measurement of melting temperature of antisense oligonucleotides and an RNA oligonucleotide with CD spectra}

Each antisense oligonucleotide along with a complementary RNA $(0.33 \mu \mathrm{M})$ were dissolved in a buffer containing $12.5 \mathrm{mM}$ phosphate buffer ( $\mathrm{pH} 6.8)$, heated at 
$95^{\circ} \mathrm{C}$ for 10 minutes, and then cooled down to room temperature. The CD spectra of the duplexes were obtained with a JASCO J-720 spectropolarimeter equipped with a Peltier temperature controller (PTC-348W, JASCO, Tokyo, Japan) from $20^{\circ} \mathrm{C}$ to $80^{\circ} \mathrm{C}$ at intervals of $0.1^{\circ} \mathrm{C}$. The melting temperature $\left(T_{\mathrm{m}}\right)$ of the duplexes was determined from changes of their molar ellipticity $(\theta)$ at $260 \mathrm{~nm}$.

\section{Construction of a plasmid vector containing mouse PADI4 gene}

Mouse spleen poly $\mathrm{A}^{+}$RNA (100 ng, Clontech, Mountain View, CA) and $1 \mu \mathrm{L}$ of $500 \mu \mathrm{g} / \mathrm{mL}$ oligo $\mathrm{p}(\mathrm{dT})_{12-18}$ cDNA primer (Roche Diagnostic, Indianapolis, IN) were dissolved with DNase and RNase free water (Sigma, St. Louis, MO) to a final volume of $15 \mu \mathrm{L}$. The mixture was incubated at $70^{\circ} \mathrm{C}$ for 10 minutes, and cooled on ice for 5 minutes. To the mixture, $5 \mu \mathrm{L}$ of $5 \times$ first strand buffer (Invitrogen, Carlsbad, CA), $2.5 \mu \mathrm{L}$ of $100 \mathrm{mM}$ DTT, 1 $\mu \mathrm{L}$ of $25 \mathrm{mM}$ dNTPs (Invitrogen), $0.5 \mu \mathrm{L}$ of $40 \mathrm{U} / \mu \mathrm{L}$ RNase inhibitor (Toyobo, Osaka, Japan) and $1 \mu \mathrm{L}$ of 200 $\mathrm{U} / \mu \mathrm{L}$ SuperScript ${ }^{\mathrm{TM}}$ II RNase $\mathrm{H}^{-}$Reverse Transcriptase (Invitrogen) were added. The mixture was incubated at $42^{\circ} \mathrm{C}$ for 90 minutes, and then at $70^{\circ} \mathrm{C}$ for 10 minutes. The first strand cDNA solution was obtained to add 25 $\mu \mathrm{L}$ of DNase and RNase free water.

The first strand cDNA was amplified with a forward primer (5'-TATTAAGCCTGGGGTAGTCCGAGGATGGCCCAGG-3'), a reverse primer (5'-TATTGCGGCCGCAAGGGAGGCTGCCTGGGGTAGTG-3') and KOD DNA polymerase (Toyobo) according to the manufacturer protocol. The desired cDNA (approximately 2 kbp) was purified with QIAquick PCR Purification Kit (Qiagen, Valencia, CA) according to the manufacturer protocol. The purified cDNA was inserted into pCRBluntII-TOPO vector and the resulting plasmid Padi4/ pCR-BluntII was isolated with a Zero Blunt TOPO PCR Cloning Kit (Invitrogen).

To construct a vector that can be expressed in mammalian cells, PADI4 cDNA in plasmid Padi4/pCR-Blunt was amplified with a forward primer (5'-GGGAAGCTTGCCACCATGCATCACCATCACCATCACGCCCAGGGTGCGGTGATCCACGTG-3'), a reverse primer (5'-CCCGGATCCTCAGTCAGTCAGGGCACCATGTGCCACCACTTGAAGGTGAAGGGCTTCC-3') and $P f x$ DNA polymerase (Invitrogen) according to the manufacturer protocol. The desired cDNA fragment (approximately $2 \mathrm{kbp}$ ) was purified with agarose gel electrophoresis and a QIAquick Gel Extraction Kit (Qiagen) according to the manufacturer's protocol. The cDNA fragment was double-digested with HindIII and BamHI, and inserted into plasmid pCR3.1 (Invitrogen) that was digested with HindIII and BamHI. The sequences of PADI4 cDNA of plasmid Padi4/pCR3.1 were confirmed with an ABI PRISM 3700 DNA sequencer (Applied Biosystems).

\section{Preparation of transcribed PADI4 mRNA}

PADI4 cDNA was amplified with a forward primer containing the T7 promoter sequence ( $5^{\prime}$-GAATTCTAATACGACTCACTATAGGGAGAC- $3^{\prime}$ ), a reverse primer (5'-TGCTGGATATCTGCAGAATTCGGCT-3') and Takara Ex Taq (Takara Bio, Shiga, Japan) according to the manufacturer's protocol. The reaction mixture was extracted with phenol- $\mathrm{CHCl}_{3}$. The amplified fragment was recovered with ethanol precipitation and purified with a Microcon YM-50 (Millipore, Billerica, MA). The cDNA fragment was transcribed with AmpliScribe T7 Transcription kits (Epicentre Biotechnologies, Madison, WI) according to the manufacturer's protocol.

\section{RNase $H$ reaction}

A 5'-FAM-labeled RNA oligonucleotide (50 pmol) was mixed with each ENA gapmer or a DNA oligonucleotide $(250 \mathrm{pmol})$ in a solution of $40 \mathrm{mM}$ Tris- $\mathrm{HCl}$ (pH 7.7), $4 \mathrm{mM} \mathrm{MgCl}, 1 \mathrm{mM}$ DTT, $4 \%$ glycerol and $0.003 \%$ bovine serum albumin (BSA), and heated at $37^{\circ} \mathrm{C}$ for 15 minutes. To the mixture, 0.075 or 0.15 units of E. coli RNase H (Takara Bio) were added. All of the reactions were incubated at $37^{\circ} \mathrm{C}$ for $15 \mathrm{~min}$ utes. Aliquots of $2 \mu \mathrm{L}$ loading solution ( $1 \mathrm{M}$ formamide, $0.25 \%$ bromophenol blue, and $0.25 \%$ xylene cyanol FF) were added to the samples. The sample mixtures were loaded and run on $15 \%$ polyacrylamide gel electrophoresis containing $7 \mathrm{M}$ urea $(1 \times$ Tris-borate ethylenediaminetetraacetic acid [EDTA] buffer). As a maker, a partial digestion reaction of the 5'FAM-labeled RNA oligonucleotide by snake venom phosphodiesterase for 2,10 , or $20 \mathrm{~min}$ was conducted (Morita et al., 2002).

In the case of transcribed PADI4 mRNA, the RNase Hmediated reaction was carried out in a total volume of 4.5 $\mu \mathrm{L}$ containing 100 pmol ENA gapmer, 18 pmol transcribed PADI4 mRNA, $40 \mathrm{mM}$ Tris- $\mathrm{HCl}$ (pH 7.7), $4 \mathrm{mM}$ $\mathrm{MgCl}_{2}, 1 \mathrm{mM}$ DTT, $4 \%$ glycerol, $0.003 \%$ BSA, 0.1 units human placenta RNase inhibitor (Takara Bio) and 1 unit of E. coli RNase H (Takara Bio). All of the reactions were incubated at $37^{\circ} \mathrm{C}$ for 15 minutes. The reaction mixture was added to a solution of $2 \mu \mathrm{L}$ of $5 \times$ formamide gel-running buffer (0.1 M MOPS [pH 7.0], $40 \mathrm{mM}$ sodium acetate, and $5 \mathrm{mM}$ EDTA), $3.5 \mu \mathrm{L}$ of $37 \%$ formaldehyde and $15 \mu \mathrm{L}$ of formamide, and immediately heated at $90^{\circ} \mathrm{C}$ for 2 minutes to stop the reaction. Aliquots of $2 \mu \mathrm{L}$ loading solution (50\% glycerol, $1 \mathrm{mM}$ EDTA pH 8.0, 0.25\% bromophenol blue, and $0.25 \%$ xylene cyanol FF) were added to the samples. The mixtures were loaded and run on $2 \%$ agarose gel electrophoresis containing formaldehyde $(1 \times$ formamide gel-running 
buffer). The gel was stained with ethidium bromide. Perfect RNA ${ }^{\mathrm{TM}}$ Markers, $0.1-1 \mathrm{~kb}$ (Novagen, Madison, WI) was used as a size marker.

The bands on the gel were visualized with a Molecular Imager FX Fluoresent Imager system (Bio-Rad, Hercules, CA), and quantified with Quantity One software (Bio-Rad). The image of the gel was optimized using Adobe Photoshop.

\section{Cell culture and oligonucleotide treatment}

Mouse fibroblast NIH3T3 cells $\left(2-3 \times 10^{5}\right.$ cells $/ \mathrm{mL}$ well) were maintained in Dulbecco's modified Eagle's medium [DMEM] with 10\% fetal bovine serum (FBS; Invitrogen) at $37^{\circ} \mathrm{C}$ in a humidified atmosphere containing $5 \% \mathrm{CO}_{2}$. Each ENA gapmer (final concentration, 500 $\mathrm{nM})$ and plasmid Padi4/pCR3.1 (2 $\mu \mathrm{g})$ was cotransfected into NIH3T3 cells with SuperFect Transfect Reagent (Qiagen). Total RNAs were isolated at 24 hours after transfection using an RNeasy 96 kit (Qiagen) and then purified with a DNA-free Kit (Ambion, Austin, TX) to remove the genomic DNA.

Mouse PADI4 mRNA was quantitated by TaqMan analysis (Applied Biosystems; Assay ID: Mm00478086_m1) with an ABI 7900HT Sequence Detection System (Applied Biosystems). The amount of mRNA in each sample was normalized against the amount of the $18 \mathrm{~S}$ ribosomal RNA with TaqMan Ribosomal RNA Control Reagents (Applied Biosystems). The values given are averages including the standard deviations of three independent experiments.

\section{RESULTS}

RNase $H$ reaction of duplexes of a $5^{\prime}$-FAM-labeled RNA oligonucleotide with DNA oligonucleotides or ENA gapmers

In order to evaluate the function of the PADI4 gene, which has been identified as a rheumatoid arthritis-susceptibility gene (Suzuki et al., 2003), ENA/DNA/ENA antisense gapmers, which are known to work inside cells, were designed (Takagi et al., 2004). Two antisense sequences of PADI4 mRNA were selected (AS-1 in Table 1 and AS-2 in Table 2). Normally, the appropriate antisense oligonucleotides are selected with a combination of control oligonucleotides, which are not related to antisense sequences such as sense sequences ( $\mathrm{S}-1$ in Table 1 and S-2 in Table 2).

First, we compared the specificity of the DNA oligonucleotides and ENA gapmers as antisense oligonucleotides on an E. coli RNase $\mathrm{H}$ reaction, which is a key enzyme to cleave target RNA (Fig. 2). A 5'-FAM-labeled RNA oligonucleotide having a target sequence was mixed with DNA oligonucleotides with an antisense sequence, DNA AS-1, 8-mismatched sequence, DNA AS-1 $8 \mathrm{MM}$, or a sense sequence, DNA S-1. The mixtures were incubated with $E$. coli $\mathrm{RNase} \mathrm{H}$ and analyzed by polyacrylamide gel electrophoresis containing $7 \mathrm{M}$ urea (Fig. $2 \mathrm{~A})$. In the case of using DNA AS-1, the 5'-FAM-labeled RNA oligonucleotide was cleaved as expected. However, cleavage of the duplex of the 5'-FAM-labeled RNA oligonucleotide with DNA AS-1 8MM, in which we expected a duplex formation with the partial region, was

Table 1. Sequences of ENA Gapmers/Mixmers and $T_{\mathrm{M}}$ Values of Duplexes of ENA GaPmers/Mixmers and Their Complementary RNA Oligonucleotide

\begin{tabular}{|c|c|c|c|c|}
\hline Name & Window $^{\mathrm{a}}$ & Sequence $\left(5^{\prime}-3^{\prime}\right)^{\mathrm{b}}$ & $\mathrm{T}_{m}\left({ }^{\circ} \mathrm{C}\right)^{\mathrm{c}}$ & Type \\
\hline AS-1 & 13 & ACG TCA CAC TGT CTT GGA ACA & 64 & Antisense \\
\hline AS-1-1 & 9 & 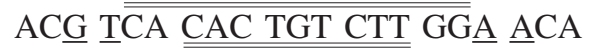 & 69 & Antisense \\
\hline AS-1-2 & 7 & ACG TCA CAC TGT CTT GGA ACA & 70 & Antisense \\
\hline AS-1-3 & 5 & ACG TCA $\underline{C A C}$ TGT CTT GGA ACA & 68 & Antisense \\
\hline AS-1-4 & None & 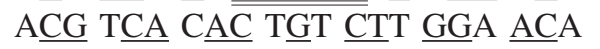 & 71 & Antisense \\
\hline S-1 & 13 & TGT TEC A $\overline{\text { AG }}$ ACA $\overline{\text { GTG TG }}$ A $\overline{C G T}$ & ND & Sense \\
\hline S-1-1 & 9 & 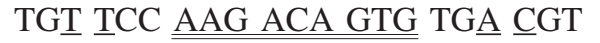 & ND & Sense \\
\hline S-1-2 & 7 & 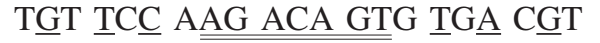 & ND & Sense \\
\hline$S-1-3$ & 5 & 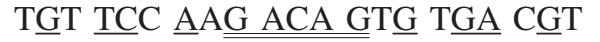 & ND & Sense \\
\hline S-1-4 & None & 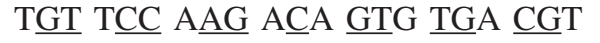 & ND & Sense \\
\hline
\end{tabular}

aWindow: Number of more than three contiguous DNA residues in the window region.

bPlain: ENA residues; underlined: DNA residues; double-underlined: contiguous DNA regions consisting of more than five DNA residues.

${ }^{\mathrm{c}} T_{\mathrm{m}}$ : melting temperature of the oligonucleotide with a complementary RNA oligonucleotide, R-1, 5'-UGU UCC AAG ACA GUG UGA CGU-3'. The $T_{\mathrm{m}}$ value of a duplex of DNA AS-1 and R-1 was $49^{\circ} \mathrm{C}$.

$\mathrm{ND}$, not determined. 
Table 2. Sequences of ENA Gapmers/Mixmers

\begin{tabular}{|c|c|c|c|}
\hline Name & Window ${ }^{\mathrm{a}}$ & Sequence $\left(5^{\prime}-3^{\prime}\right)^{\mathrm{b}}$ & Type \\
\hline AS-2 & 10 & TCT TCG TGC TTA GGG TCA & Antisense \\
\hline AS-2-1 & 6 & 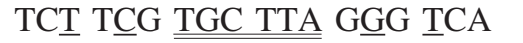 & Antisense \\
\hline AS-2-2 & 5 & TCT TCG TGC TTA GGG TCA & Antisense \\
\hline AS-2-3 & None & TCT TCG TGC TTA GGG TCA & Antisense \\
\hline S-2 & 10 & TGA CCC TAA GCA CGA AGA & Sense \\
\hline S-2-1 & 6 & TGA C드 TAA GCA C $\underline{\text { TA }} \underline{A} \underline{A} A$ & Sense \\
\hline S-2-2 & 5 & TGA $\underline{C} \underline{C} \underline{T}$ TA GCA CGA $\underline{A G A}$ & Sense \\
\hline S-2-3 & None & TGA $\underline{C C C} \underline{T A A}$ GCA C $\underline{\text { GA AGA }}$ & Sense \\
\hline
\end{tabular}

${ }^{a}$ Window: Number of more than three contiguous DNA residues in the window region.

bPlain: ENA residues; underlined: DNA residues; double-underlined: contiguous DNA regions consisting of more than five DNA residues.

observed. Even the mixture of the 5'-FAM-labeled RNA oligonucleotide and DNA S-1 showed slight cleaved products when incubated with a high concentration of RNase $\mathrm{H}$. These results demonstrate that when DNA oligonucleotides partially hybridize to RNA, RNase $\mathrm{H}$ hydrolyzes the resulting hybrid. These results are comparable to the previous reports, which showed that DNA/RNA duplexes containing mismatched sequences were substrates for RNase $\mathrm{H}$ at slower rates than that of completely paired DNA/RNA duplexes (Lima et al., 1997; Shen et al., 1998).

On the other hand, when an ENA gapmer, AS-1, was used as the antisense strand the 5'-FAM-labeled RNA oligonucleotide was specifically cleaved in the RNase $\mathrm{H}$ reaction (Figs. 2A and 2B). Although AS-1 formed a stable duplex with the 5'-FAM-labeled RNA oligonucleotides in the absence of RNase $\mathrm{H}$, once RNase $\mathrm{H}$ cleaved the substrate, we could observe cleaved products on the gel (Figs. 2A and B). The duplex of ENA gapmers with an 8 mismatch sequence, AS-1 8MM, in the RNase $\mathrm{H}$ reaction showed a small amount of cleaved products in the only high concentration of RNase H (Fig. 2B). In the case of an ENA gapmer with the sense sequence S-1, no cleavage was observed. These results suggest that use of ENA gapmers as antisense oligonucleotides, which have a shorter DNA region than unmodified DNA oligonucleotides, diminishes the undesired cleavage and improves the specificity of antisense oligonucleotides.

RNase $H$ reaction of duplexes of a full-length transcript of the PADI4 gene with ENA gapmers containing the short DNA region

To further verify the specificity of ENA gapmers, we conducted an in vitro E. coli $\mathrm{RNase} \mathrm{H}$ reaction analysis using a full-length transcript of the PADI4 gene (approximately 2150 nucleotides) and ENA gapmers. When using an ENA gapmer, AS-1, two desired cleavage bands (approximately 920 and 1230 nucleotides) and some minor undesired bonds were mainly observed (Fig. 3A). The mixture of the transcript and an ENA gapmer with the sense sequence $\mathrm{S}-1$, was cleaved at nontarget sites by RNase $\mathrm{H}$ derived from the partial base-pairing between the transcript and the ENA gapmer, although no cleavage was observed when using the $5^{\prime}$-FAM-labeled RNA oligonucleotide, as shown in Figure 2B. The five binding sites of S-1 on the transcript of the PADI4 gene with more than five contiguous base-pairs, which are induced as the substrates for RNase $\mathrm{H}$, were predicted as shown in Figure 3B. Five predicted sites corresponded with the size of the bonds on the gel (Fig. 3B).

In the previous section, we found that length of the DNA region of antisense oligonucleotides influenced the specific cleavage by RNase $\mathrm{H}$. When the DNA window region of the ENA gapmers AS-1 and S-1 was shortened to 9,7 or 5 nucleotides such as ENA gapmers, AS-1-1, AS-1-2, AS-1-3, S-1-1, S-1-2 and S-1-3 (Table 1), the nontarget cleavage using the ENA gapmers AS-1-3 and S-1-3 with 5 DNA nucleotides was diminished and the target-site specific cleavage by the use of AS-1-3 was observed in the in vitro E. coli RNase $\mathrm{H}$ reaction analysis (Fig. 3A). ENA mixmers without more than three contiguous DNA regions, AS-1-4 and S-1-4, were used as negative controls. For these ENA gapmer designs, eight ENA residues were incorporated in each ENA gapmer to obtain an affinity similar to the target mRNA. Indeed, the melting temperature values $\left(T_{\mathrm{m}}\right)$ of the duplexes of these ENA gapmers with a complementary RNA oligonucleotide, R-1, were observed, as shown in Table 1 . The $T_{\mathrm{m}}$ values of duplexes of ENA gapmers and R-1 were obviously higher than that of natural DNA/RNA duplex, DNA S-1/R-1. The values of these ENA gapmers were relatively similar and were unlikely to be correlated with the target-site specific cleavage, as shown in Figure 3A.

To verify the generality of the sequence-specific cleavage by ENA gapmers with a short DNA region, a series 

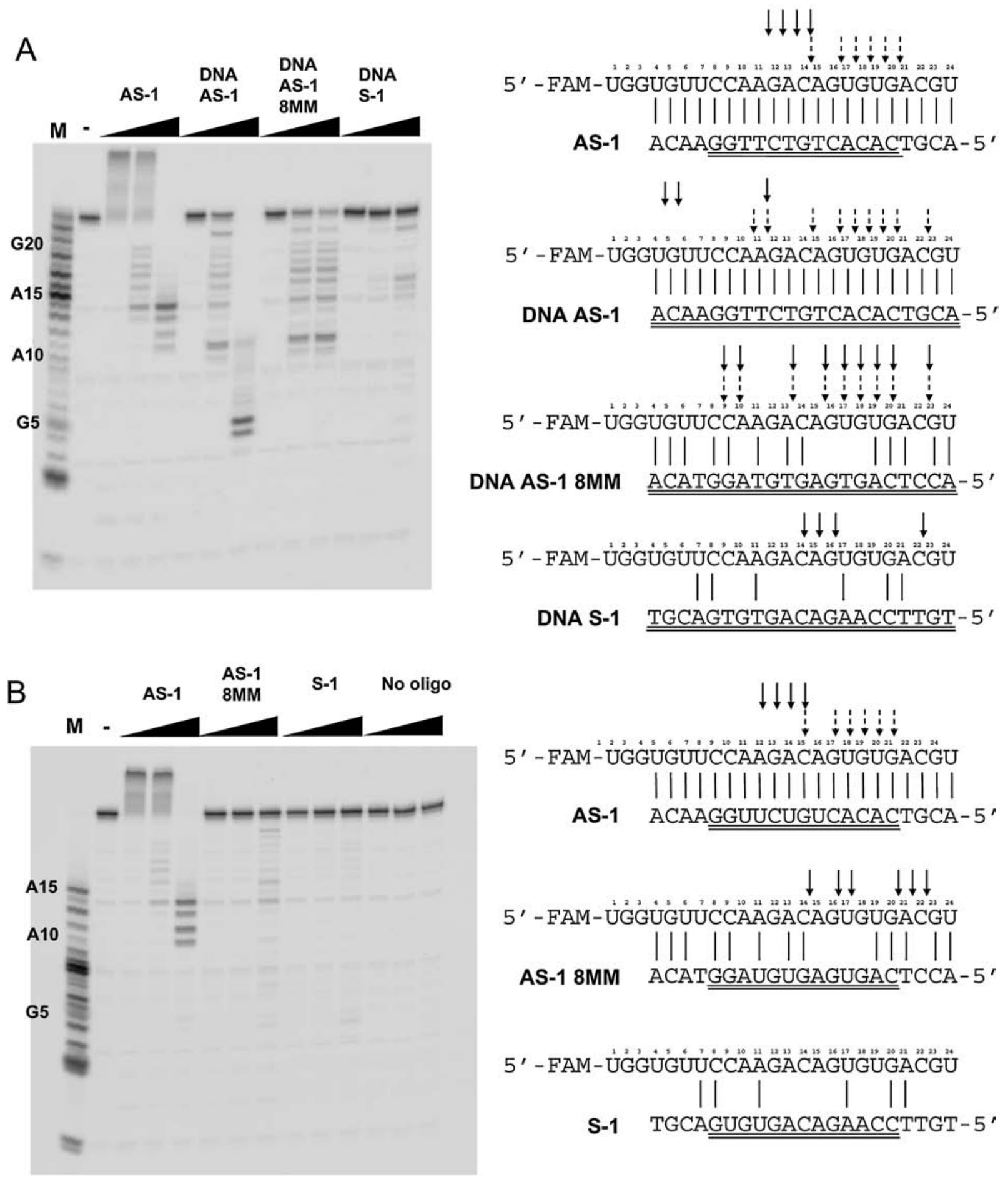

FIG. 2. A: RNase $H$ reaction of a 5'-FAM-labeled R-1 and an antisense strand such as AS-1, DNA AS-1, DNA AS-1 8MM, or DNA S-1. The indicated oligonucleotides were incubated with 5'-FAM-labeled R-1 in the absence of RNase H or in the presence of 0.075 or 1.5 units of RNase H (from left to right). -: control 5'-FAM-labeled R-1 without any oligonucleotide added; M: digestion products by snake venom phosphodiesterase (SVPD) for 10 minutes. Contiguous DNA regions consisting of more than five DNA residues were double-underlined. Dash and solid arrows indicate cleaved sites in the presence of 0.075 or 1.5 units of RNase $\mathrm{H}$, respectively. Exact cleavage sites were determined by RNase T1 digestion products (data not shown). B: RNase H reaction of 5'-FAM-labeled R-1 and an antisense strand such as AS-1, AS-1 8MM, or S-1. The indicated oligonucleotides were incubated with $5^{\prime}$-FAM-labeled R-1 in the absence of RNase H or in the presence of 0.075 or 1.5 units of RNase H (from left to right). -: control 5'-FAM-labeled R-1 without any oligonucleotide added; No oligo: incubation of 5'-FAM-labeled R-1 without any oligonucleotide added in the presence of RNase H; M: mixture of SVPD digestion reaction for 2 minutes and 20 minutes. Contiguous DNA regions consisting of more than five DNA residues were double-underlined. Dash and solid arrows indicate cleaved sites in the presence of 0.075 or 1.5 units of RNase $H$, respectively. 


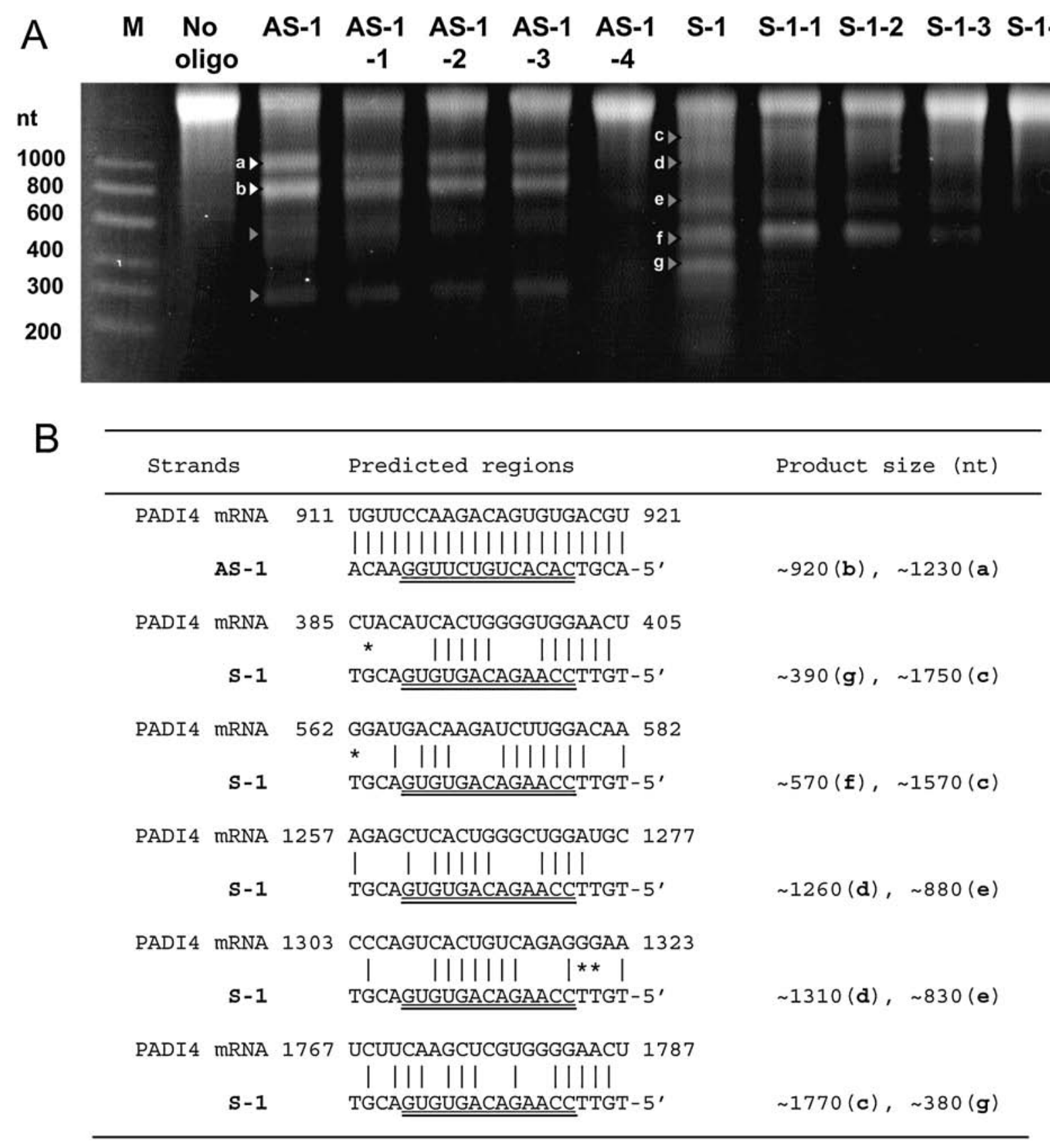

FIG. 3. A: Cleavage reaction of in vitro transcribed PADI4 mRNA (approximately $2150 \mathrm{nt}$ ) with RNase $\mathrm{H}$ in the absence of an oligonucleotide or in the presence of an oligonucleotide such as AS-1, AS-1-1 to -1-4, S-1 or S-1-1 to -1-4. Open and closed arrow heads $(\mathbf{a}-\mathbf{g})$ indicate desired and undesired bands, respectively. B: Predicted regions of full and partial complementarities that may form base pairs between in vitro transcribed PADI4 mRNA (approximately $2150 \mathrm{nt}$ ) and AS-1 or S-1. "|" and "*” represent Watson-Crick base pairs and wobble base pairs, respectively. The contiguous DNA region of AS-1 or S-1 was double-underlined. Sizes of proposed fragments are indicated. The bands $\mathbf{a}$ and $\mathbf{b}$ in the lane "AS-1" of (A) indicate cleaved products. On the basis of fragment sizes bands $\mathbf{c}-\mathbf{g}$, which were observed in the lane "S-1" of (A), are proposed in parentheses.

of ENA gapmers with other target sequences were designed, as shown in Table 2. When the DNA window region of the ENA gapmers AS-2 and S-2 was shortened to 6 or 5 nucleotides such as ENA gapmers, AS-2-1, AS-22, S-2-1, and S-2-2, the nonspecific cleavage using the
ENA gapmers S-2-1 and S-2-2 was obviously diminished in comparison with the cleavage reaction by use of the parent ENA gapmer S-2 with a wide DNA region. On the other hand, the target-site cleavage by use of AS-2-1 and AS-2-2 was almost maintained (Fig. 4A). ENA mixmers 
without more than three contiguous DNA regions, AS-23 and S-2-3, did not work in this reaction. These results indicate that use of ENA gapmers with 5 or 6 DNA nucleotides as the window region improves the specificity on the RNase $\mathrm{H}$ reaction with a combination of inactive control ENA gapmers with sense sequences.

Specific inhibition of PADI4 mRNA expression by fine-tuning ENA gapmers

To investigate whether the ENA gapmers show specific inhibitory activity in cells, the inhibitory assay on PADI4 mRNA expression by ENA gapmers was conducted. A PADI4 mRNA-expressed plasmid and each ENA gapmer were cotransfected into mouse NIH3T3 cells, and then the amount of PADI4 mRNA was comparatively quantified by TaqMan PCR (Fig. 4B). While the ENA oligonucleotide S-2-3, which has no more than
3 contiguous DNA regions with a sense sequence, was the inactive control, the ENA gapmer S-2, with a sense sequence and a wide 13 DNA nucleotide region in the window, reduced the expression of the PADI 4 mRNA by $49 \%$. However, the ENA gapmers S-2-1 and S-2-2 with a sense sequence and a 6 or 5 DNA nucleotide region were almost inactive. On the other hand, the ENA gapmers AS-2, AS-2-1 and AS-2-2 with a 10, 6, or 5 DNA nucleotide region, inhibited the PADI4 mRNA expression by $11 \%, 22 \%$, and $31 \%$, respectively. These results suggest that a combination of ENA gapmers, with AS-2-1 as the antisense oligonucleotide and S-2-1 as the sense oligonucleotide, was sufficient for the target validation of the PADI4 gene. These intracellular results of PADI4 mRNA downregulation by the ENA gapmers, as shown in Figure 4B, were relatively correlated with the results of the in vitro RNase $\mathrm{H}$ reaction by the ENA gapmers as shown in Figure 4A.
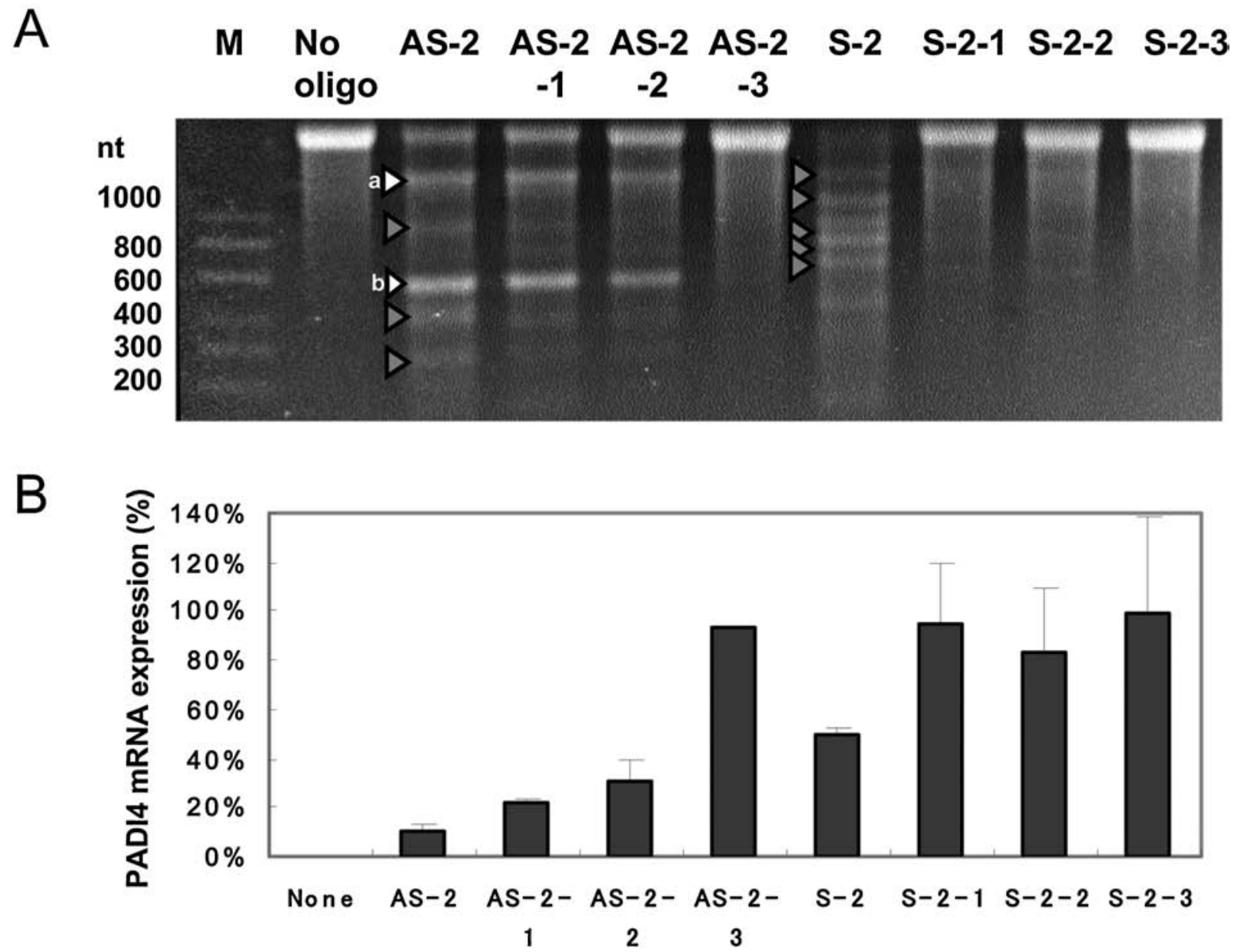

FIG. 4. A: RNase $\mathrm{H}$ reaction of in vitro transcribed PADI4 mRNA (approximately $2150 \mathrm{nt}$ ) with RNase $\mathrm{H}$ in the absence of an oligonucleotide or the presence of an oligonucleotide such as AS-2, AS-2-1 to -2-3, S-2, or S-2-1 to -2-3. Open and closed arrow heads indicate desired (a: $\sim 610 \mathrm{nt}$; b: $\sim 1540 \mathrm{nt}$ ) and undesired bands, respectively. B: Inhibition of mouse PADI4 mRNA expression in NIH3T3 cells treated with ENA gapmers/mixmers. The amount of mouse PADI4 mRNA in each sample was normalized against the amount of $18 \mathrm{~S}$ ribosomal RNA. 


\section{DISCUSSION}

The sequence-specific design of antisense oligonucleotides has been discussed for more than two decades. Antisense oligonucleotides with a length of 15 nucleotides were calculated to have a specific frequency on the basis of the genome size (Hélène and Toulmé, 1989). However, duplexes of RNA and antisense oligonucleotides with mismatch base pairs are substrates for RNase $\mathrm{H}$, which causes less specificity of antisense strategy (Woolf et al., 1992). This is called an "off-target" effect, and is known to be one of the problems with small interference RNA technologies (Dykxhoorn et al., 2003; Sledz et al., 2003)

To resolve this problem, the use of gapmers with DNA methylphosphonate as both wings, which show lower affinity than unmodified DNA, have been reported (Giles et al., 1992; Larrouy et al., 1992). The DNA region of these gapmers was shortened, resulting in an improvement of nuclease stability and increased specificity due to a restricted DNA region sensitive to RNase $\mathrm{H}$.

As a similar molecular design, both wings of antisense oligonucleotides have been modified with high affinity nucleotides such as 2'-O-alkyl RNA (Larrouy et al., 1995; Lima et al., 1997; Shen et al., 1998). An in vitro wheat germ translation assay of $\alpha$ - and $\beta$-globin selective synthesis, which involved RNase $\mathrm{H}$ activity, gapmers with $2^{\prime}$-OMe RNA as the wings and 5 DNA nucleotides as the window, did not improve the specificity in comparison with natural DNA, where the authors speculated that high-affinity antisense oligonucleotides decreased the specificity (Larrouy et al., 1995). On the other hand, Shen et al. (1998) observed a greater than 50\% difference in the cleavage between the matched and single mismatched target by $E$. coli RNase $\mathrm{H}$ with gapmers containing the $2^{\prime}$-OMe RNA region as both wings and 4 DNA nucleotides in the window. Kinetic analysis of an E. coli RNase $\mathrm{H}$ reaction with duplexes of 2'-OMe RNA gapmers and the target RNA revealed that the initial cleavage rates of single mismatched duplexes decreased by threefold over the matched duplexes (Lima et al., 1997). These discrepancies may derive from the target sequences, the mismatched position and/or the ternary structures of the target RNA.

The design of gapmers containing $2^{\prime}, 4^{\prime}$-BNA/LNA or $\alpha$ L-LNA, which had extremely high affinity to RNA, was optimized to recruit RNase $\mathrm{H}$ and was stable in human serum or a nuclease reaction (Kurreck et al., 2003; Freden et al., 2003). However, in these papers, they did not describe the relationship between the DNA window size and the target specificity. Previously, we reported that the wing length of ENA gapmers was shortened to reduce off-target effects in human cancer cells (Morita et al., 2006).

In the present paper, we showed the cleavage of transcribed PADI4 mRNA by E. coli RNase $\mathrm{H}$ with ENA gapmers containing various sizes of the DNA window and ENA residues, which had extremely high affinity to RNA as well as $2^{\prime}, 4^{\prime}$-BNA/LNA. Although the ENA gapmers with a wide DNA window exhibited the specific cleavage of the short synthetic RNA oligonucleotide (Fig. 2), the nonspecific cleavage of transcribed PADI4 mRNA as the target was observed due to partial base pairing (Figs. 3A and 4A). While the DNA nucleotides in the window of the ENA gapmers were shortened to 5 or 6 nucleotides, the specific cleavage of their transcribed PADI 4 mRNA by E. coli RNase H was observed (Figs. $3 \mathrm{~A}$ and $4 \mathrm{~A}$ ). Our strategy, which was the introduction of a shorter DNA region, such as 5 or 6 DNA residues in the ENA gapmers, was shown to improve their sequence specificity, even if the ENA gapmers with high affinity to the target RNA, which have much higher affinity than that of 2'-OMe RNA, were utilized. Our results were consistent with Shens results using gapmers with $2^{\prime}$ OMe RNA as antisense strands (Shen et al., 1998).

Recently, although gapmers with a wide DNA window were being used for antisense oligonucleotides to improve the efficacy of the target mRNA downregulation, no detailed characterization of the specificity against non-target mRNA has yet been reported (Monia et al., 2006; Lima et al., 2007b). Obviously, a wide DNA window would be readily recognized by RNase $\mathrm{H}$, however, its mismatched duplexes with RNA also would be substrates for RNase $\mathrm{H}$, causing nontarget-specific cleavage.

In conclusion, we suggest the utilization of antisense oligonucleotides with a short DNA region to reduce the possibility of undesired reactions such as off-target effects. We should be alert to the utility of antisense oligonucleotides with a wide DNA region in terms of sequence specificity.

\section{REFERENCES}

BAKER, B.F., LOT, S.S., CONDON, T.P., CHENGFLOURNOY, S., LESNIK, E.A., SASMOR, H.M., and BENNETT, C.F. (1997). 2'-O-(2-Methoxy)ethyl-modified anti-intercellular adhesion molecule 1 (ICAM-1) oligonucleotides selectively increase the ICAM-1 mRNA level and inhibit formation of the ICAM-1 translation initiation complex in human umbilical vein endothelial cells. J. Biol. Chem. 272, 11994-12000.

BRAASCH, D.A., LIU, Y., and COREY, D.R. (2002). Antisense inhibition of gene expression in cells by oligonucleotides incorporating locked nucleic acids: effect of mRNA target sequence and chimera design. Nucleic Acids Res. 30, 5160-5167.

BUTLER, M., McKAY, R.A., POPOFF, I.J., GAARDE, W.A., WITCHELL, D., MURRAY, S.F., DEAN, N.M., BHANOT, S., and MONIA, B.P. (2002). Specific inhibition of PTEN expression reverses hyperglycemia in diabetic mice, Diabetes $\mathbf{5 1}, \mathbf{1 0 2 8 - 1 0 3 4 .}$ 
CROOKE, S.T., LEMONIDIS, K.M., NEILSON, L., GRIFFEY, R., LESNIK, E.A., and MONIA, B.P. (1995). Kinetic characteristics of Escherichia coli RNase H1: cleavage of various antisense oligonucleotide-RNA duplexes. Biochem. J. 312, 599-608.

CROOKE, R.M., GRAHAM, M.J., LEMONIDIS, K.M., WHIPPLE, C.P., KOO, S., and PERERA, R.J. (2005). An apolipoprotein $\mathrm{B}$ antisense oligonucleotide lowers LDL cholesterol in hyperlipidemic mice without causing hepatic steatosis. J. Lipid Res. 46, 872-884.

DYKXHOORN, D.M., NOVINA, C.D., and SHARP, P.A. (2003). Killing the messenger: short RNAs that silence gene expression. Nat. Rev. Mol. Cell. Biol. 4, 457-467.

FRIEDEN, M., CHRISTENSEN, S.M., MIKKELSEN, N.D., ROSENBOHM, C., THRUE, C.A., WESTERGAARD, M., HANSEN, H.F., ORUM, H., and KOCH, T. (2003). Expanding the design horizon of antisense oligonucleotides with alpha-L-LNA. Nucleic Acids Res. 31, 6365-6372.

GILES, R.V., and TIDD, D.M. (1992). Increased specificity for antisense oligodeoxynucleotide targeting of RNA cleavage by RNase $\mathrm{H}$ using chimeric methylphosphonodiester/phosphodiester structures. Nucleic Acids Res. 20, 763-770.

HELENE C., and TOULME J.J. (1989). Oligodeoxynucleotides: Antisense Inhibitors of Gene Expression. J.S. Cohen, ed. (MacMillan Press, London), pp 137-172.

HORIE, M., MORITA, K., KAWAKAMI, J., TSUTSUMI, S., ANDO, O., and KOIZUMI, M. (2006). Comparison between properties of $2^{\prime}-O, 4^{\prime}-C$-ethylene-bridged nucleic acid $\left(\mathrm{ENA}^{\circledR}\right)$ phosphorothioate oligonucleotides and N3'-P5' thiophosphoramidate oligonucleotides, Nucleosides Nucleotides Nucleic Acids 25, 231-242.

INOUE, H., HAYASE, Y., IWAI, S., and OHTSUKA, E. (1987). Sequence-dependent hydrolysis of RNA using modified oligonucleotide splints and RNase H. FEBS Lett. 215, 327-330.

JEPSEN, J.S., PFUNDHELLER, H.M., and LYKKESFELDT, A.E. (2004). Downregulation of p21(WAF1/CIP1) and estrogen receptor alpha in MCF-7 cells by antisense oligonucleotides containing locked nucleic acid (LNA). Oligonucleotides 14, 147-156.

KOIZUMI, M., TAKAGI-SATO, M., OKUYAMA, R., ARAKI, K., SUN, W., NAKAI, D., TSUTSUMI, S., and KAWAI, K. (2006). Direct comparison of in vivo antisense activity of ENA oligonucleotides targeting PTP1B mRNA with that of $2^{\prime}$-O-(2-methoxy)ethyl-modified oligonucleotides. Oligonucleotides 16, 253-262.

KOIZUMI, M. (2006) ENA oligonucleotides as therapeutics. Curr. Opin. Mol. Ther. 8, 144-149.

KOSHKIN, A.A., SINGH, S.K., NIELSEN, P., RAJWANSHI, V.K., KUMAR, R., MELDGAARD, M., OLSEN, C.E., and WENGEL, J. (1998). LNA (locked nucleic acids): synthesis of the adenine, cytosine, guanine, 5-methylcytosine, thymine and uracil bicyclonucleoside monomers, oligomerisation, and unprecedented nucleic acid recognition. Tetrahedron 54, 3607-3630.

KURRECK, J. (2003). Antisense technologies. Improvement through novel chemical modifications. Eur. J. Biochem. 270, 1628-1644.

KURRECK, J., WYSZKO, E., GILLEN, C., and ERDMANN, V.A. (2003). Design of antisense oligonucleotides stabilized by locked nucleic acids. Nucleic Acids Res. 30, 1911-1918.

LARROUY, B.L., BLONSKI, C., BOIZIAU, C., STUER, M., MOREEAU, S., SHIRE D., and TOULME, J.-J. (1992) RNase H-mediated inhibition of translation by antisense oligodeoxyribonucleotides: use of backbone modification to improve specificity. Gene 121, 189-194.

LARROUY, B., BOIZIAU, C., SPROAT, B., and TOULME, J.-J. (1995). RNase H is responsible for the non-specific inhibition of in vitro translation by $2^{\prime}-O$-alkyl chimeric oligonucleotides: high affinity or selectivity, a dilemma to design antisense oligomers. Nucleic Acids Res. 23, 3434-3440.

LIMA, W.F., and CROOKE, S.T. (1997). Binding affinity and specificity of Escherichia coli RNase H1: impact on the kinetics of catalysis of antisense oligonucleotide-RNA hybrids. Biochemistry 36, 390-398.

LIMA, W., ROSE. J.B., NICHOLS, J.G., WU, H., MIGAWA, M.T., WYRZYKIEWICZ, T.K., SIWKOWSKI, A.M., and CROOKE, S.T. (2007a). Human RNase H1 discriminates between subtle variations in the structure of the heteroduplex substrate. Mol. Pharmacol. 71, 83-91.

LIMA, W., ROSE. J.B., NICHOLS, J.G., WU, H., MIGAWA, M.T., WYRZYKIEWICZ, T.K., VASQUEZ, G., SWAYZE, E.E., and CROOKE, S.T. (2007b). The positional influence of the helical geometry of the heteroduplex substrate on human RNase H1 catalysis. Mol. Pharmacol. 71, 73-82.

MONIA, B.P., LESNIK, E.A., GONZALEZ, C., LIMA, W.F., McGEE, D., GUINOSSO, C.J,, KAWASAKI, A.M., COOK, P.D., and FREIER, S.M. (1993). Evaluation of $2^{\prime}$-modified oligonucleotides containing $2^{\prime}$-deoxy gaps as antisense inhibitors of gene expression. J. Biol. Chem. 268, 1451414522.

MONIA, B.P., SIWKOWSKI, A.W., and BHANOT, S. (2006). Enhanced antisense oligonucleotides. WO2006/034348 (May 30, 2006).

MORITA, K., HASEGAWA, C., KANEKO, M., TSUTSUMI, S., SONE, J., ISHIKAWA, T., IMANISHI, T. and KOIZUMI, M. (2002) 2'-O,4'-C-Ethylene-bridged nucleic acids (ENA): highly nuclease-resistant and thermodynamically stable oligonucleotides for antisense drug. Bioorg. Med. Chem. Lett. 12, 73-76.

MORITA, K., TAKAGI, M., HASEGAWA, C., KANEKO, M., TSUTSUMI, S., SONE, J., ISHIKAWA, T., IMANISHI, T., and KOIZUMI, M (2003). Synthesis and properties of 2'$O, 4^{\prime}-C$-ethylene-bridged nucleic acids (ENA) as effective antisense oligonucleotides. Bioorg. Med. Chem. 11, 22112226.

MORITA, K., YAMATE, K., KURAKATA, S., ABE, K., WATANABE, K., IMANISHI, T., and KOIZUMI, M. (2006). Inhibition of VEGF mRNA by 2'-O,4'-C-ethylenebridged nucleic acids (ENA) antisense oligonucleotides and their influence on off-target gene expressions. Nucleosides Nucleotides Nucleic Acids. 25, 503-521.

OBIKA, S., NANBU, D., HARI, Y., MORIO, K., IN, Y., ISHIDA, T., and IMANISHI, T. (1997). Synthesis of 2'$O, 4^{\prime}$ - $C$-methyleneuridine and -cytidine. Novel bicyclic nucleosides having a fixed $\mathrm{C}^{\prime}$ '-endo sugar puckering. Tetrahedron Lett. 38, 8735-8738.

OBIKA, S., UNEDA, T., SUGIMOTO, T., NANBU, D., MINAMI, T., DOI, T., and IMANISHI, T. (2001). $2^{\prime}-O, 4^{\prime}-C$ - 
Methylene bridged nucleic acid (2',4'-BNA): synthesis and triplex-forming properties. Bioorg. Med. Chem. 9, 10011011.

ORUM, H. (2005). Engineering genomics. RNA antagonistsa new class of antisense drugs. IEEE Eng. Med. Biol. Mag. 24, 81-87.

SAZANI, P., GEMIGNANI, F., KANG, S.H., MAIER, M.A., MANOHARAN, M., PERSMARK, M., BORTNER, D., and KOLE, R. (2002). Systemically delivered antisense oligomers upregulate gene expression in mouse tissues. Nat. Biotechnol. 20, 11228-11233.

SHEN, L.X., KANDIMALLA, E.R., and AGRAWAL, S. (1998). Impact of mixed-backbone oligonucleotides on target binding affinity and target cleaving specificity and selectivity by Escherichia coli RNase H. Bioorg. Med. Chem. 6, 1695-1705.

SLEDZ, C.A., HOLKO, M., De VEER, M.J., SILVERMAN, R.H., and WILLIAMS, B.R. (2003). Activation of the interferon system by short-interfering RNAs. Nat. Cell. Biol. 5, 834-839.

SURONO, A., Van KHANH, T., TAKESHIMA, Y., WADA, H., YAGI, M., TAKAGI, M., KOIZUMI, M., and MATSUO, M. (2004). Chimeric RNA/ethylene-bridged nucleic acids promote dystrophin expression in myocytes of duchenne muscular dystrophy by inducing skipping of the nonsense mutation-encoding exon. Hum. Gene. Ther. 15, 749-757.

SUZUKI, A., YAMADA, R., CHANG, X., TOKUHIRO, S., SAWADA, T., SUZUKI, M., NAGASAKI, M., NAKAYAMA-HAMADA, M., KAWAIDA, R,, ONO, M., OHTSUKI, M., FURUKAWA, H., YOSHINO, S., YUKIOKA, M., TOHMA, S., MATSUBARA, T., WAKITANI, S., TESHIMA, R., NISHIOKA, Y., SEKINE, A., IIDA, A., TAKAHASHI, A., TSUNODA, T., NAKAMURA, Y., and YAMAMOTO, K. (2003). Functional haplotypes of PADI4, encoding citrullinating enzyme peptidylarginine deiminase 4 , are associated with rheumatoid arthritis. Nat. Genet. 34, 395-402.

TAKAGI, M., MORITA, K., NAKAI, D., NAKAGOMI, R., TOKUI, T., and KOIZUMI, M. (2004). Enhancement of the inhibitory activity of oatp antisense oligonucleotides by incorporation of $2^{\prime}-O, 4^{\prime}-C$-ethylene-bridged nucleic acids (ENA) without a loss of subtype selectivity. Biochemistry 43, 4501-4510.

TAKAGI-SATO, M., TOKUHIRO, S., KAWAIDA, R., and KOIZUMI, M., (2006). Design of ENA gapmers as fine-tun- ing antisense oligonucleotides with sequence-specific inhibitory activity on mouse PADI4 mRNA expression. Nucleic Acids Symp. Ser. No. 50, 319-320.

WOOLF, T.M., MELTON, D.A., and JENNINGS, C.G. (1992). Specificity of antisense oligonucleotides in vivo. Proc. Natl. Acad. Sci. USA 89, 7305-7309.

WU, H., LIMA, W.F., and CROOKE, S.T. (1999). Properties of cloned and expressed human RNase H1. J. Biol. Chem. 274, 28270-28278.

YU, X.X., MURRAY, S.F., PANDEY, S.K., BOOTEN, S.L., BAO, D., SONG, X.Z., KELLY, S., CHEN, S., McKAY, R., MONIA, B.P., and BHANOT, S. (2005). Antisense oligonucleotide reduction of DGAT2 expression improves hepatic steatosis and hyperlipidemia in obese mice. Hepatology $\mathbf{4 2 ,}$ 362-371.

ZHANG, H., COOK, J., NICKEL, J., YU, R., STECKER, K., MYERS, K., and DEAN, N.M. (2000). Reduction of liver Fas expression by an antisense oligonucleotide protects mice from fulminant hepatitis. Nat. Biotechnol. 18, 862-867.

ZINKER, B.A., RONDINONE, C.M., TREVILLYAN, J.M., GUM, R.J., CLAMPIT, J.E., WARING, J.F., XIE, N., WILCOX, D., JACOBSON, P., FROST, L., KROEGER, P.E., REILLY, R.M., KOTERSKI, S., OPGENORTH, T.J., ULRICH, R.G., CROSBY, S., BUTLER, M., MURRAY, S.F., McKAY, R.A., BHANOT, S., MONIA, B.P., and JIROUSEK, M.R. (2002). PTP1B antisense oligonucleotide lowers PTP1B protein, normalizes blood glucose, and improves insulin sensitivity in diabetic mice. Proc. Natl. Acad. Sci. USA 99, 11357-11362.

Address reprint requests to: Dr. Makoto Koizumi Advanced Technology Research Laboratories Daiichi Sankyo Co., Ltd. 1-2-58, Hiromachi Shinagawa-ku Tokyo 140-8710 Japan

E-mail: koizumi.makoto.h7@daiichisankyo.co.jp

Received February 27, 2007; accepted in revised form April 18, 2007. 